\title{
Evaluation of the Efficacy of Autologous Bone Marrow Stem Cell Transplantation in Type 1 Diabetes Mellitus.
}

\author{
Serag EI Din O. S.; Magda S. Hassanin; Eman A. Sherif; Khaled M. Makboul \\ and Alaa E. Ismail* \\ Zoology Department, Women`s College, Ain Shams University. \\ *Surgery Medicine, Ain Shams University.
}

\begin{abstract}
Diabetes mellitus (DM) is characterized by hyperglycaemia that is often associated with long- term complication, including microvascular (retinopathy, nephropathy, and neuropathy) macro vascular damage. The present study was designed to evaluate the possible role of autologous bone marrow stem cell transplantation for cases of type 1 DM, which could differentiate into insulin- producing $\beta$ cells and its role in modulating the immune response from $\mathrm{T}$ helper 1 to $\mathrm{T}$ helper 2 . This study was conducted on 10 cases of autoimmune type 1 diabetes mellitus, both males and females. They were selected according to inclusion and exclusion criteria. We observed that $70 \%$ of studied subjects decreased in their insulin requirements. Fasting and postprandial blood glucose significantly decreased after transplantation, while levels of C-peptide were significantly increased at the end of 9 months of autologous bone marrow- derived stem cell transplantation (SCT). But glycated haemoglobin significantly decreased after transplantation. No side effects were noted in liver and kidney functions. Our observations indicated that SCT is a safe and effective modality of treatment to improve $\beta$ - cell function in patients with T1DM.
\end{abstract}

\section{Key Words: Type 1 Diabetes Mellitus / Stem cell therapy / Transplantation}

\section{Introduction}

Diabetes mellitus (DM) is a common metabolic disorder resulting from defects in insulin secretion or action or both, resulting in impaired metabolism of carbohydrates, lipids, proteins, water and electrolytes (Rasineni $\boldsymbol{e t}$ al.,2010 and Saumya and Basha, 2011). Chronic hyperglycemia was found to increase the production of free radicals that is associated with long-term damage, dysfunction and failure of various organs, especially kidney, nerves, heart and blood vessels (Heidari et al., 2008; Arora $\boldsymbol{e t}$ al.,2009 and Teoh et al.,2010).

Type 1 diabetes mellitus (DM) results from a cell-mediated autoimmune attack against pancreatic beta cells (American Diabetes Association, 2004), Type 1 diabetes only $5 \%$ to $10 \%$ of all diabetic etiologies but is associated with a high frequency of vascular complications and compromises quality and expectancy of life.

Corresponding author: emanadel23@yahoo.com 
There are two distinct phases in progression of type 1 diabetes. The first phase called insulitis, is characterized by invasion of islet tissue by a population of leukocytes ( $\mathrm{T}$ lymphocytes) in the islet tissue. Insulitis occurs only when $\beta$-cell is present, indicating that this is a specific $\beta$-cell-targeted process. The second phase corresponds to $\beta$ - cell destruction and the subsequent lack of insulin (Mathis $\boldsymbol{e t}$ al., 2001 and Roep., 2003) . The pathogenic immune response is mediated by $\mathrm{T}$ helper 1 (Th1) subset of $\mathrm{T}$ cells, whereas the protective immune response is mediated by a $\mathrm{T}$ helper 2 (Th2) subset of T cells (Rabinovitch et al., 1998).

Stem cells have two important characteristics that distinguish them from other types of cells. First, they are unspealized cells that renew themselves for long periods through cell division (Watt and Hagan, 2000). The second is that under certain physiologic or experimental conditions, they can be induced to become cells with special functions such as the beating cells of the heart muscle or the insulin producing cells of pancreas. There are two types of stem cells, embryonic stem cells and adult stem cells (Anne et al., 2010).

Bone Marrow is an important and easily accessible source of adult stem cells .Use of Autologous bone marrow -derived stem cell is safe and devoid of any ethical issues .Bone Marrow Transplantation (BMT) is becoming a powerful strategy in treating autoimmune diseases such as rheumatoid arthritis (RA), insulin dependent diabetes mellitus (IDDM) and chronic glomerulonephritis. Bone marrow (BM) contains hematopoietic stem cells and mesenchymal stem cells , both of which exhibit considerable developmental plasticity, An initial report that BM stem cells could engraft into pancreatic islets in vivo and differentiate to insulin - expressing phenotype (Ianus et al.,2003) could not be confirmed by other groups (Efrat.,2008) .

On the other hand, studies of Watada and colleagues suggested that bone marrow derived cells are a distinct cell population from islet cells and that transdifferentiation from bone marrow derived cells to pancreatic $\beta$ cells is a rare event (Choi et al.,2003; Lechner et al.,2004) .

The present study was taken to evaluate the possible role of autologous bone marrow stem cell transplantation for cases of type $1 \mathrm{DM}$, which could differentiate into insulin- producing $\beta$ cells, and its role in modulating the immune response from $T$ helper 1 to $\mathrm{T}$ helper 2 .

\section{Material and Methods}

This study was conducted on cases of auto immune type 1 Diabetes Mellitus. The selected groups of patients were enrolled in this study in (Ain Shams University Hospitals in the Pancreatic Islet Transplantation and diabetes Research Unit). They were selected according to inclusion and exclusion criteria and who agreed to sign a written consent.

\section{Included patients:}

Study Group: ten patients were enrolled in this study. 


\section{Inclusion criteria:}

- Diabetic cases type 1 within 5-10 years of diagnosis

- Age above 15 years.

- Both males and females.

\section{Exclusion criteria:}

- Receiving medications that depress patient's immune system.

- Patients with recurrent diabetic ketoacidosis.

- Pregnancy and lactation (history and pregnancy test in suspicious cases)

- Presence of other auto immune disorder eg. Extrinsic asthma, Graves' disease (history and clinical examination).

- Presence of allergic conditions eg. Atopy

- Patients having congestive heart failure (clinically and by echocardiography).

- Patients with chronic liver disease or renal impairment (clinically and by liver and kidney function tests).

\section{Study procedures}

\section{a) Pre-Transplantation assessment :}

\section{All patients were subjected to:}

1-Complete medical history taking and thorough clinical examination

2-Fasting and post prandial blood sugar

3-Hemoglobin $\mathrm{A}_{1} \mathrm{C}$

4- C-peptide

5-Liver function tests (AST, ALT and serum albumin).

6-Kidney function tests (serum urea, BUN and Creatinine).

\section{b) Transplantation}

Bone marrow blood aspiration under local anaesthesia

\& Harvesting

* Mononuclear layer to be injected intra venously.

\section{c) Post -injection follow up:}

Follow up of temporal changes in exogenous insulin requirements (daily dose and duration of usage). Secondary end points: Serum levels of hemoglobin A1C, Cpeptide levels for 3 months post injection.

Serum was separated for the assessment of carbohydrate related parameters (glucose according to the method adapted by (Trinder,1969), liver function parameters ( Albumin according to Doumas et al.(1971), Alanine aminotransferase (ALT) and Aspartate aminotransferase (AST) according to Bergmeyer et al.(1978). Kidney function parameters (serum urea according to Fawcett and Scott (1960) and creatinine according to Seeling and Wust (1969). C-peptide (Krause et al.,1981), Also, fresh whole blood was obtained in heparinized test tubes to determine the glycoslated haemoglobin (HbA1c) according to (Klenk, 1991). 


\section{Statistical analysis}

Data were analyzed using the SPSS for windows soft ware, version 17

\section{Results and Discussion}

\section{Results}

Table (1): Change in insulin requirement after transplantation during 9 months of follow up. This table shows that $70 \%$ of studied subjects decreased in their insulin requirement while $10 \%$ of studied subjects no changed, but still $20 \%$ of studied subjects increased.

Table (2): Liver function parameters pre and post transplantation. This table shows no change in ALT, AST and Albumin pre and post transplantation.

Table (3): Kidney function parameters pre and post transplantation. This table shows no change in urea, blood urea nitrogen (BUN) and creatinine pre and post transplantation.

Table (4): Fasting and post prandial blood sugar parameters pre and post transplantation in patients with type $1 \mathrm{DM}$. This table shows that fasting blood sugar and post prandial blood sugar significantly decreased post transplantation with ($176 \%$ and $-25.5 \%$ ) respectively after 9 months of follow up period.

Table (5): Comparison of C-peptide parameter pre and post transplantation in patients with type $1 \mathrm{DM}$. This table shows that C-peptide highly significant increased after 3, 6 and 9 months with $(215 \%, 360 \%$ and 533\%) respectively.

Table (6): Comparison of HbA1c parameter pre and post transplantation in patients with type $1 \mathrm{DM}$. This table shows that HbA1c slightly decreased after 3 months and significantly decreased after 6 and 9 months with $(-2.8 \%,-4.6 \%$ and $-7.6 \%)$ respectively.

Table (1): Change in insulin requirement after transplantation during 9 months of follow up.

\begin{tabular}{|c|c|c|}
\hline \multicolumn{2}{|c|}{$\begin{array}{c}\text { Change in total insulin } \\
\text { requirement after transplantation. }\end{array}$} \\
\hline \hline & $\mathbf{N}$ & $\%$ \\
\hline Increased & 2 & 20.00 \\
\hline Decreased & 7 & 70.00 \\
\hline No change & 1 & 10.00 \\
\hline Total & 10 & 100.00 \\
\hline \hline
\end{tabular}

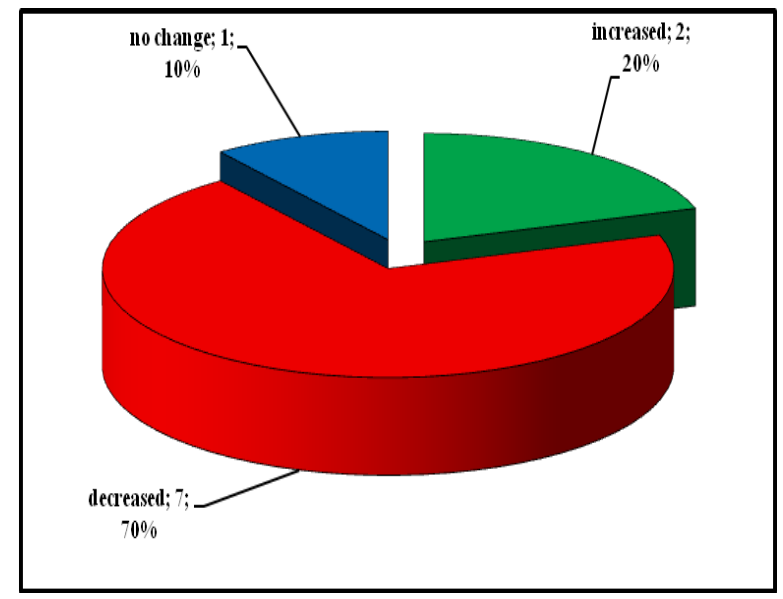


Table (2): Liver function parameters pre and post transplantation.

\begin{tabular}{|c|c|c|c|c|}
\hline \multicolumn{2}{|c|}{$\begin{array}{l}\text { Pre and post } \\
\text { Transplantation }\end{array}$} & AST & ALT & Albumin \\
\hline \multirow{2}{*}{ 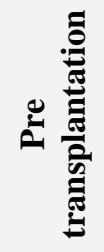 } & Range & $20-31$ & $19-30$ & 3.9-4.9 \\
\hline & Mean \pm S.E & $25 \pm 1.23$ & $24.3 \pm 1.06$ & $4.33 \pm 0.12$ \\
\hline \multirow{4}{*}{ 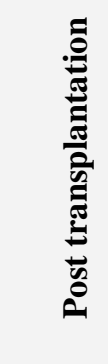 } & Range & $21-30$ & $20-30$ & $3.9-4.8$ \\
\hline & Mean \pm S.E & $25 \pm 1.09$ & $24.8 \pm 0.93$ & $4.28 \pm 0.11$ \\
\hline & $\%$ of change & Zero & 2.05 & -1.15 \\
\hline & $P$ value & N.S & N.S & N.S \\
\hline
\end{tabular}

Table (3): Kidney function parameters pre and post transplantation.

\begin{tabular}{|c|c|c|c|c|}
\hline \multicolumn{2}{|c|}{$\begin{array}{l}\text { Pre and post } \\
\text { Transplantation }\end{array}$} & Urea & BUN & Creatinine \\
\hline \multirow{2}{*}{ 苑 } & Range & $17-36$ & 14-20 & 0.89-1.2 \\
\hline & Mean \pm S.E & $25.9 \pm 2.0$ & $16.1 \pm 0.06$ & $1.06 \pm 0.04$ \\
\hline \multirow{4}{*}{ 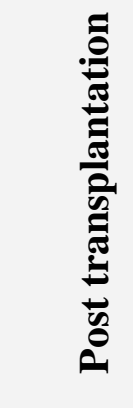 } & Range & $19-35$ & 14-20 & $0.9-1.2$ \\
\hline & Mean \pm S.E & $26 \pm 1.72$ & $16.2 \pm 0.59$ & $1.05 \pm 0.03$ \\
\hline & $\%$ of change & 0.38 & 0.62 & -1.62 \\
\hline & P va & N.S & N.S & N.S \\
\hline
\end{tabular}

$P$ value $<0.001$ highly significant $P$ value $<0.05$ Significant

N.S: Non Significant $>0.05$ S.E: Standard Error 
Table (4): Fasting and post prandial blood sugar parameters pre and post transplantation in patients with type $1 \mathrm{DM}$.

\begin{tabular}{|c|c|c|c|}
\hline \multicolumn{2}{|c|}{$\begin{array}{c}\text { Pre and post } \\
\text { Transplantation }\end{array}$} & $\begin{array}{c}\text { Fasting blood } \\
\text { sugar }\end{array}$ & $\begin{array}{c}\text { Post prandial } \\
\text { blood sugar }\end{array}$ \\
\hline \multirow{2}{*}{ 䜦 } & Range & 20-31 & $19-30$ \\
\hline & Mean \pm S.E & $25 \pm 1.226$ & $24.3 \pm 1.05$ \\
\hline \multirow{4}{*}{ 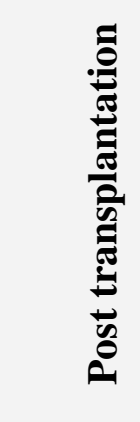 } & Range & 21-30 & $20-30$ \\
\hline & Mean \pm S.E & $25 \pm 1.08$ & $24.8 \pm 0.93$ \\
\hline & $\%$ of change & -17 & -25.5 \\
\hline & $P$ value & $P<0.001$ & $P<0.001$ \\
\hline
\end{tabular}

$P$ value $<0.001$ highly significant $P$ value $<0.05$ Significant N.S: Non Significant $>0.05$ S.E: Standard Error

Table (5): Comparison of C-peptide parameter pre and post transplantation in patients with type $1 \mathrm{DM}$.

\begin{tabular}{|c|c|c|c|}
\hline \multicolumn{2}{|c|}{$\begin{array}{l}\begin{array}{l}\text { Pre and post } \\
\text { Transplantation }\end{array} \\
\end{array}$} & & C-peptide \\
\hline \multicolumn{2}{|c|}{ Pre transplantation } & Range & $0.5-3.6$ \\
\hline \multirow{12}{*}{ 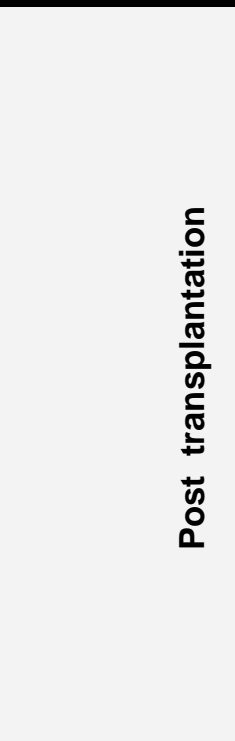 } & \multirow{4}{*}{ After 3 months } & Don & $15-63$ \\
\hline & & Mean \pm S.E & $4.19 \pm 0.55$ \\
\hline & & $\%$ of change & 215 \\
\hline & & $P$ value & $\mathbf{P}<0.001$ \\
\hline & \multirow{4}{*}{ After 6 months } & Range & $2-9$ \\
\hline & & Mean \pm S.E & $6.12 \pm 0.84$ \\
\hline & & $\%$ of change & 360 \\
\hline & & $P$ value & $P<0.001$ \\
\hline & \multirow{4}{*}{ After 9months } & Range & $2.2-14.9$ \\
\hline & & Mean \pm S.E & $8.42 \pm 1.36$ \\
\hline & & $\%$ of change & 533 \\
\hline & & $P$ value & $\mathbf{P}<0.001$ \\
\hline
\end{tabular}


Table (6): Comparison of HbA1c parameter pre and post transplantation in patients with type $1 \mathrm{DM}$.

\begin{tabular}{|c|c|c|c|}
\hline \multicolumn{3}{|c|}{$\begin{array}{l}\begin{array}{l}\text { Pre and post } \\
\text { Transplantation }\end{array} \\
\end{array}$} & HbA1c \\
\hline \multirow{2}{*}{\multicolumn{2}{|c|}{ Pre transplantation }} & Range & $7.0-9.2$ \\
\hline & & Mean \pm S.E & $8.22 \pm 0.21$ \\
\hline \multirow{8}{*}{ 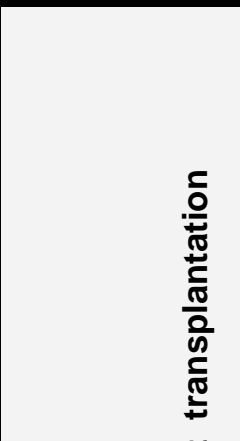 } & \multirow{4}{*}{ After 3 months } & Range & $7-9$ \\
\hline & & Mean \pm S.E & $8.05 \pm 0.2$ \\
\hline & & $\%$ of change & -2.8 \\
\hline & & P value & N.S \\
\hline & \multirow{4}{*}{ After 6 months } & Range & $7.2-9$ \\
\hline & & Mean \pm S.E & $7.84 \pm 0.2$ \\
\hline & & $\%$ of change & -4.6 \\
\hline & & $P$ value & $P<0.05$ \\
\hline \multirow{4}{*}{$\begin{array}{l}\text { চ } \\
\text { வ }\end{array}$} & \multirow{4}{*}{ After 9months } & Range & $6.9-8.9$ \\
\hline & & Mean \pm S.E & $7.59 \pm 0.23$ \\
\hline & & $\%$ of change & -7.6 \\
\hline & & $P$ value & $P<0.05$ \\
\hline
\end{tabular}

\section{$P$ value $<0.001$ highly significant $\quad P$ value $<0.05$ Significant N.S: Non Significant $>0.05$ S.E: Standard Error}

\section{Discussion}

The change in the daily total insulin requirement utilized by all enrolled subjects was increased in $20 \%$ of studied subjects, decreased in $70 \%$ of studied subjects this agreed with the study done by Snarski et al (2011); who found that 11 of 13 patients required significantly lower doses of insulin for adequate glycemic control during the follow-up period.

In our present study we found that the daily insulin requirement no changed in $10 \%$ of studied subjects also all the patient enrolled in our study did not experience any time free from insulin this is against the study done by Voltarelli et al (2007); who reported that thirteen of 15 patients experienced continuous time free from insulin and 1 patient became transiently insulin free after Autologous nonmyeloablative hematopoietic stem cell transplantation in newly diagnosed type 1 diabetes mellitus.

In type 1 diabetes there is selective destruction of beta-cells associated with severe or complete insulin deficiency, thereby making administration of exogenous insulin mandatory (Chakraborti, 2008). Autoimmune destruction in type 1 diabetes is precipitated by environmental factors in genetically susceptible individuals (Muthukrishnan et al., 2007). Type 1 diabetes is diagnosed when the patient's endogenous insulin secretion decreases to a level which results in hyperglycemia (Palmer, 2009). 
Diabetes disturbs the liver function, due to which the activities of SGOT and SGPT were increased in the blood as observed by Ahmad et al. (2008).

In diabetic patients, elevated enzymatic activity of SGOT with only moderately increase in SGPT activity suggested cardiac damage while elevated activity of SGPT with only moderate increase in SGOT suggested liver damage as reported by (Sundaram et al.(2009). SGOT and SGPT enzymes are responsible for production of ketone bodies from aminoacids. The higher activities of SGOT and SGPT were suggested to be the cause for a high concentration of glucose. The gluconeogenic action of SGOT and SGPT plays the role of providing new supplies of glucose from other sources such as amino acids (Asaduzzaman $\boldsymbol{e t}$ al., 2010). The normal activities of SGOT and SGPT are < $38 \mathrm{U} / 1$ and < $41 \mathrm{U} / 1$ respectively (Tietz, 1999).

In the present study both SGOT and SGPT activities were found to be within normal values indicating that there was no liver damage.

Diabetic nephropathy occurs in approximately one third of diabetics. A quick and simple way to check renal function in diabetics is to draw blood sample for serum creatinine and blood urea tests (Wagle, 2010). Elevation of the plasma urea and creatinine which are the significant renal function markers, may be due to metabolic disturbance in diabetes reflected in high activities of xanthine oxidase, lipid peroxidation, increased triacylglycerol and cholesterol levels (Chandramohan et al., 2009). Due to continuous catabolism of amino acids, high urea is likely to be formed from urea cycle (Lal et al., 2009 and Ortin et al., 2010).

After many years of diabetes, the delicate filtering system in the kidney becomes destroyed. Increment of blood urea level with the increment of blood glucose level clearly indicates that the increased blood glucose level causes damage to the kidney (Shrestha et al., 2008). The reference range for blood urea is $14-50 \mathrm{mg} / \mathrm{dl}$ (Kohli et al., 2008). The reference range for serum creatinine is $0.741 .5 \mathrm{mg} / \mathrm{dl}$ (ElShenawy and Abdel-Nabi, 2006 and Ceriotti et al., 2008).

In the present study, both urea and creatinine were within normal levels at diagnosis as well as after stem cell transplantation indicating that there was no kidney damage.

A significant decrease $(\mathrm{p}<0.001)$ was observed in fasting and Post prandial blood glucose levels among diabetic patients after stem cell transplantation.

These result came close to study done by Feihong et al (2013); who found during a 12- to 18-month follow-up for 7 patients underwent AHSCT that the fasting, post prandial blood glucose were decreased range from 3.9-6.0 $\mathrm{mmol} / \mathrm{L}$.

Insulin reduces hepatic glucose output and increases peripheral glucose utilization (Rahman et al., 2009). The decrease in both the fasting blood glucose and postprandial blood glucose level in the present study might be due to the hypoglycemic effects of insulin which in turn would have been mediated by decreased hepatic glucose output and increased peripheral glucose utilization.

The improvement in the glycemic status of diabetic patients in the present study might be due to expansion of $\beta$-cell mass and/or improvement of $\beta$-cell function. The present study confirmed the therapeutic effect of stem cell transplantation in patients with type 1 diabetes mellitus, which is evidenced by a significant decrease in both 
fasting and postprandial glucose levels after intervention (Monnier and Colette, 2009).

Glucose monitoring is a key component in diabetes (Zhou et al., 2009). Human C-peptide provides an accurate assessment of residual beta-cell function and thus has been widely used as a marker of insulin secretion in patients with diabetes (Wiedmeyer et al., 2007). Assay of HbA1c serves as a reliable measure of chronic glycemia and correlates well with the risk of long term diabetes related complications (The International Expert Committee, 2009).

Malini et al. (2011) reported that C-peptide is the product of the enzymatic cleavage of proinsulin and secreted into the circulation in equimolar concentrations. The measurement of $\mathrm{C}$ - peptide level has been reported to be a valuable index of insulin secretion. C- peptide has insulin-mimetic effects on its own by activating insulin receptors, and increasing glycogen synthesis and amino acid uptake. The Cpeptide promotes insulin action at low concentrations and inhibits it at high levels, suggesting a modulatory effect by C-peptide on insulin signaling (Sriram and Subramanian,2011).

C-peptide is secreted from islet cells into the circulation in equi molar concentrations with insulin and is not extracted by the liver. Hence, C-peptide levels are used as a biomarker of $\beta$-cell function (Ko et al., 2009). A moderate correlation was observed by Abdullah et al. (2010) between body mass index (BMI), HbA1c and fasting C-peptide levels. The destruction of insulin producing $\beta$-cells in type 1 diabetes is caused by a $\beta$-cell specific autoimmune process (Yoon and Jun, 2005).

In our study we found that C-peptide is highly significant increased after 3, 6 and 9 months which agreed with the study done by Ablamunits et al (2007); who found that the concentrations of serum C-peptide was significantly increased in patients for at least 6 months after autologous hematopoietic stem cell transplantation.

Also this result agreed with the study done by Carlos et al (2009); who did a prospective study on 23 patients with type 1 DM (aged 13-31 years) recently diagnosed and confirmed by measurement of serum levels of anti-glutamic acid decarboxylase antibodies showed that the C-peptide levels increased significantly after a mean follow-up of 29.8 months following autologous nonmyeloablative HSCT.

Glycosylated haemoglobin (HbAlc) is a glycosylated derivative of haemoglobin used primarily to identify the average plasma glucose concentration over prolonged periods of time. Glycosylated haemoglobin (HbA1c) is produced by nonenzymatic condensation of glucose molecules with free amino acids on the globin component of haemoglobin (Beissuenger et al.,1993). The higher level of glucose led to elevation in HbA1c. it is useful in demonstration of glycemic control over a period of 8-12 weeks, which is the life span of RBCs.

The HbA1c level is proportional to average blood glucose concentration over the previous preceding four weeks to three months. As the average amount of plasma glucose increases, the fraction of glycated hemoglobin increases in a predictable way (Sellamuthu et al.,2009 and Bandawane et al.,2011). Several reports indicated that 
the measurement of glycosylated derivatives of haemoglobin in blood provides a good indication of the long-term efficacy of diabetic control (Tembhurne and Sakarkar,2010 and Sriram and Subramanian,2011).

Moreover, Sriram and Subramanian (2011) suggested that a high glucose concentration has been found to lead to the glycosylation of amino groups of lysine residue in proteins. Non enzymatic glycosylation of protein occurs by direct reaction between reducing sugars and amino groups in protein. This condition favors reduction in the level of total hemoglobin and elevation in glycosylated hemoglobin, which is directly proportional to blood glucose.

In present study we found that the HbA1C is slightly decreased after 3 months and significantly decreased after 6 and 9 months. This agreed with the study done by Couri et al, (2009); who found that the mean pre-transplant $\mathrm{HbA} 1 \mathrm{C}$ was $8 \%$ and decreased significantly $(\mathrm{p}<.001)$ at $3,12,24,36$ and 48 months to 5.4\%, 5.7\%, 5.7\%, $5.5 \%$ and $6.0 \%$, respectively.

Also this result agreed with the study done by Otonkoski et al (2005); who found that the average $\mathrm{HbA} 1 \mathrm{c}$ concentration was $11.5 \%$ at diagnosis, $5.88 \%$ at 6 months and $5.76 \%$ at 12 months following AHSC transplantation in 15 patients (age 19 - 32) with early diagnosis of type 1 diabetes.

\section{Acknowledgments}

We would like to thank Dr. Ola Serag El Din, Dr. Magda Hassanin, Dr. Alaa Ismail for their help in the preparation of the manuscript.

\section{References}

Abdullah, B.B.; Patil, B.S and Thaseen, A. (2010): "Significance of C-peptide in type 2 diabetics - A study in the North Karnataka population of India, Al. Ameen Journal of Medical Science, 3,65 -78.

Ablamunits, V.; Sherry, N.A. and Kushner, J.A. (2007): "Autoimmunity And beta cell regeneration in mouse and human type 1 diabetes: the peace is not enough. Ann NY Acad Sci; 1103:19-32.

Ahmad, M.; Zaman, F.; Sharif, T. and Zabta, M. (2008 ) : "Antidiabetic and hypolipidemic effects of aqueous methanolic extract of Acacia nilotica pods in alloxan-induced diabetic rabbits, Scandinavian Journal of Laboratory Animal Science, 35, 129-34.

American Diabetes Association. (2004): " Diagnosis and classification of diabetes mellitus, Diabetes Care, 27(1): S5-S10. 
Anne, C.; Brignier, M.D.; Alan, M. and Gewirtz, M.D. (2010): " Embryonic and adult stem cell therapy. J. Allergy Immunol. 125(2):S336-S344.

Arora, S.; Ojha, S. K. and Vohora, D. (2009): "Characterization of streptozotocin induced diabetes mellitus in swiss albino mice. Glob. J. Pharmacol., 3 (2): 8184.

Asaduzzaman, Akhtalz, A.; Islam, A.; Khan, R.I.; Anisuzzamanz and Ahmed, M. (2010): "Evaluation of antidiabetic, antihyperlipidemic and hepatoprotective effects of Allium Sativum (Linn.) in alloxan induced diabetic rats, Bangladesh Pharmaceutical Journal, 13, 28-33.

Bandawane, D.; Juvekar, A. and Juvekar, M. (2011): "Antidiabetic and Antihyperlipidemic Effect of Alstonia scholaris Linn Bark in Streptozotocin Induced Diabetic Rats". Ind. J. Pharm. Edu. Res. 45(2):114-120.

Beissuenger, P.J.; Healy, J.C. and Shultz, E.K. (1993): "Glycosylated serum proteins and glycosylated hemoglobin in the assessment of glycemic control in IDDM and NIDDM.Diabet., 43:420-430.

Bergmeyer, R.; Henry, R.J.; et al. (1978):" Optimization of methods for Aspartate aminotransferase and Alanine aminotransferase. J. Clin. Biochem. 24: 58-73.

Carlos, E.B.; Couri, M.D.; Maria, C.B.; et al. (2009): "C-Peptide Levels and Insulin Independence Following Autologous Nonmyeloablative Hematopoietic Stem Cell Transplantation in Newly Diagnosed Type 1 Diabetes Mellitus, JAMA; 301(15):1573-1579.

Ceriotti, F.; Boyd, J.C.; Klein, G.; Henny, J., Queralto, J., Kairisto, V and Panteghini, M. (2008): " Reference intervals for serum creatinine concentrations: assessment of available data for global application Clinical Chemistry, 54, 559-566.

Chakraborti, C.K. (2008): "The potential role of vildagliptin in the management and prevention of type 2 diabetes mellitus, Indian Journal of Pharmacology, $40,10-14$. 
Chandramohan, G.; Al-Numair, K. S and Pugalendi, K. V . (2009): "Effect of hydroxymethyl xylitol on hepatic and renal functional-3 markers and protein levels in streptozotocin diabetic rats, African Journal of Biochemistry Research, 3, 198-204.

Choi, J.B.; Uchino, H.; Azuma, K.; Iwashita, N.; Tanaka, Y.; Mochizuki, H.; Migita, M.; Shimada, T.; Kawamori, R. and Watada , H. (2003): "Little evidence of trans- differentiation of bone marrow-derived cells into pancreatic beta cells Diabetologia 46:1366-1374.

Couri, C.E.; Oliveira, M.C.; Stracieri, A.B.; Moraes, D.A.; Pieroni, F.; Barros, G.M.; Madeira, M.I.; Malmegrim, K.C.; Foss-Freitas, M.C.; Simoes, B.P.; Martinez, E.Z.; Foss, M.C.; Burt, R.K. and Voltarelli, J.C. (2009): "Cpeptide levels and insulin independence following autologous nonmyeloablative hematopoietic stem cell transplantation in newly diagnosed type 1 diabetes mellitus, JAMA, (Apr 2009), Vol.301, No.15, pp.1573-9.

Doumas, B.T.; et al. (1971): "Method of Albumin analysis. Clin. Chim. Acta; 31: 87-96.

Efrat, S. (2008): "Beta-cell replacement for insulin-dependent diabetes mellitus. Adv. Drug Deliv. Rev.60, 116-123.

El-Shenawy, N.S.; Abdel-Nabi, I. M. (2006): "Hypoglycemic effect of Cleome droserifolia ethanolic leaf extract in experimental diabetes, and on nonenzymatic antioxidant, glycogen, thyroid hormone and insulin levels, Diabetologia Croatica, 15-22. 35.

Fawcett, J.K. and Scott, J.E. (1960): "Determination of urea. J. Clin. Path.; 13:156159.

Feihong Luo.; Yijin Gao.; Xiaowen Qian.; et al. (2013): "Autologous nonmyeloablative hematopoietic stem cell transplantion in newly diagnosed childhood type 1 diabetes mellitus: the first year report International Journal of Pediatric Endocrinology (Suppl 1):O31. doi:10. 1186/1687-9856-2013-S1-O31 
Heidari, Z.; Harati, M.; Mahmoudzadeh-Sagheb, H.R. and Moudi, B. (2008): "Beta cell protective effects of sodium tungstate in streptozotocin-induced diabetic rats: Glycemic control, blockage of oxidative stress and beta cell histochemistry. Iran. Biomed., 12(3): 143-152.

Ianus, A.; Holz, G.G.; Theise, N.D. \& Hussain, M.A.(2003): In vivo derivation of glucose competent pancreatic endocrine cells from bone marrow without evidence of cell fusion”. J , Clin , Invest ; 111: 843 -850 .

Klenk, S. (1991): "Glycosylated haemoglobin as monitoring of diabetes mellitus. Clin. Chem., 28:2088-2094.

Ko, G.T.C.; So, W.Y.; Tong, P.C.; Chan, W.B.; Yang, X.; Ma R.C.; Kong, A.P.; Ozaki, R.; Yeung, C.Y.; Chow, C.C and Chan, J.C. (2009): "Effect of interactions between $\mathrm{C}$ peptide levels and insulin treatment on clinical outcomes among patients with type 2 diabetes mellitus Canadian Medical Association Journal, 180, 919-26.

Kohli, U.; Lodha, $\mathbf{R}$ and Bragga, A. (2008): "Familial systemic lupus erythematosus with hypercalcemia, $75,855-857$.

Krause, U.B.; Von Erdmann, W.; Atzopodien and Beyer, J. (1981): "C-peptide measurement: A simple method for the improvement of specificity. J. Immuno., 2:33.

Lal, S.S.; Sukla, Y.; Singh, A.; Andriyas, E.A and Lall, A.M. (2009): "Hyperuricemia, high serum urea and hypoproteinemia are the risk factor for diabetes, Asian Journal of Medical Sciences, 1, 33-34.

Lechner, A.; Yang, Y.G.; Blacken, R.A.; Wang, L.; Nolan, A.L. and Habener, J.F. (2004): "No evidence for significant transdifferentiation of bone marrow into pancreatic beta-cells in vivo. Diabetes 53:616-623.

Malini, P.; Kanchana, G. and Rajadurai, M. (2011): "Antidiabetic efficacy of eliagic acid in streptozotocin induced diabetes mellitus in albino wister rats. Asian. J. Pharm. Clin. Res., 4(3): 124-128. 
Mathis, D.; Vence, L. and Benoist, C. (2001) : " $\beta$ - cell death during progression to diabetes". Nature ; 414: 792- 8 .

Monnier, L and Colette, C. (2009): "Target for glycemic control, Diabetes Care, 32, S199-S204.

Muthukrishnan, J.; Kiranmayi, L .; Verma, A and Modi, A.D. (2007): "Type 1 diabetes mellitus: correlation between etiological factors and associated conditions, International Journal of Diabetes in Developing Countries, 27, 46-49.

Ortin, X.; Rodriguez-Luaces, M.; Bosch, R., Lejeune, M. and Font, L. (2010): "Acute liver failure as the first manifestation of very late relapsing of Hodgkin's disease, Hematology Reports, 2, e5

Otonkoski, T.; Gao, R. and Lundin, K. (2005): "Stem cells in the treatment of diabetes. Ann Med; 37: 513-520.

Palmer, J.P. (2009): "C-peptide in the natural history of type 1 diabetes, Diabetes/Metabolism Research and Reviews, 25, 325-328.

Rabinovitch, A. and Suarez-Pinzon, W.L. (1998): "Cytokines and their roles in pancreatic islet $\beta$-cell destruction and insulin dependent diabetes mellitus. Biochem Pharmacol; 55(8):1139-49.

Rahman, S.; Ismail, A.A. and Rahman, A.R. (2009): " Treatment of diabetic vasculopathy with rosiglitazone and ramipril: Hype or hope?, International Journal of Diabetes in Developing Countries, 29,110-117.

Rasineni, K.; Bellamkonda, R.; Singareddy, S.R and Desireddy, S. (2010): "Antihyperglycemic activity of catharanthus roseus leaf powder in streptozotocin-induced diabetic rats. Pharmacognosy Res., 2 (3): 195-201.

Roep, B.O. (2003): "The role of T- cells in the pathogenesis of type 1 diabetes : from cause to cure". Diabetologia ; 46: $305-21$. 
Saumya, S.M. and Basha, P. (2011): "Antioxidant effect of Lagerstroemia Speciosa Pers (Banaha) leaf extract in Streptozotocin-induced diabetic mice. Ind. J. Exper. Bio., 49: 125-131.

Seeling, F. and Wust, T. (1969): "Modified methodology determination of Creatinine .J. Clin. Biochem.; 2(4): 169-176.

Sellamuthu, P.S.; Muniappan, B.P.; Perumal, S.M. and Kandasamy, M. (2009): "Antihyperglycemic effect of mangiferin in streptozotocin induced diabrtic rats. J. Health Sci., 55(2): 206-214.

Shrestha, S.; Gyawali, P.; Shrestha, R.; Poudel, B.; Sigdel, M.; Regmi, P.; Shrestha, M and Yadav, B.K. (2008): "Journal of Nepal Association for Medical Laboratory Sciences, 9, 11-12.

Snarski, E.; Milczarczyk, A.; Torosian, T.; et al. (2011): "Independence of exogenous insulin following immune-ablation and stem cell reconstitution in newly diagnosed diabetes type I. Bone Marrow Transplant 46:562-566.

Sriram, P. G. and Subramanian, S. (2011): "Fistin, a bioflavonoid ameliorates hyperglycemia in streptozotocin - induced experimental diabetes in rats. Inter. J. Pharmaceutical Sci. Review Res., 6 (1): 68-74.

Sundaram, E.N.; Reddy, P.M. and Singh, K.P. (2009): "Effect of alcoholic extracts of Indian medicinal plants on the altered enzymatic activities of diabetic rats, Indian Journal of Pharmaceutical Sciences, 71, 594-598.

Tembhurne, S.V. and Sakarkar, D.M. (2010): "Protective effect of Murraya koenigii (L) leaves extract in streptozotocin induced diabetic rats involving possible antioxidant mechanism. J. Med. Plants Res.,4(22):2418-2423.

Teoh, S.L.; Latiff, A.A. and DAS, S. (2010): "Histological changes in kidneys of experimental diabetic rats fed with Momordica charantia (bitter gourd) extract. Romanian J. Morphol. Embryol., 51(1): 91-95. 
The International Expert Committee. (2009): " International Expert Committee report on the role of the A1C assay in the diagnosis of diabetes, Diabetes Care, 32, 1327-1334.

Tietz, (1999): "Text book of Clinical Chemistry, Third edition, Philadelphia, W.B.Saunders Company, 621-721.

Trinder, P. (1969): "Glucose GOD-PAP method enzymatic colorimetric method. Ann. Clin. Biochem., 6:24.

Voltarelli, J.C.; Couri, C.E.; Stracieri, A.B.; Oliveira, M.C.; Moraes ,D.A.; Pieroni, F.; Barros, G.M.; Madeira, M.I.; Malmegrim, K.C.; FossFreitas, M. C.; Simoes, B.P.; Foss, M.C.; Squiers, E. and Burt, R.K. (2007): "Autologous hematopoietic stem cell transplantation for type 1 diabetes. Ann N Y Acad Sci 1150:220-229.

Wagle, T.J. (2010): "Gender wise comparison of serum creatinine and blood sugar levels in type-2 diabetic patients, Bombay Hospital Journal, 64, 52-68.

Watt, F. and Hogan, B. (2000): "Out of Eden: stem cells and their niches. Science; 287: $1427-1430$.

Wiedmeyer, H.M.; Polonsky, K.S.; Myers, G.L.; Little, R.R.; Greenbaum, C.J.; Goldstein, D.E. and Palmer, J.P. (2007): "International Comparison of CPeptide Measurements, Clinical Chemistry, 53, 784-787.

Yoon, J.W. and Jun, H.S. (2005): "Autoimmune destruction of pancreatic beta cells, American Journal of Therapeutics, 12, 580-91.

Zhou, J.; Hong, L.i.; Xingwu, R.; Wenying, Y.; Qiang, L.i.; Yongde, P.; Yanbing, L.i.; Xin, G.; Xiaojun, L.; Weiqing, W and Weiping, J.(2009): "Reference values for continuous glucose monitoring in Chinese subjects, Diabetes Care, 32, 1188-1193. 


$$
\text { الملخص العربي }
$$

تقييم كفاءة زر ع الخلايا الجذعية ذاتية المنشأ المستخلصة من النخاع العظمى فى مرض البول

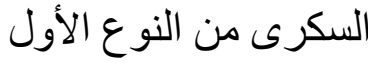

أ.د علا سر اج الدينـ أ.م.د ماجدة سيد حسنين- م. ايمان عادل شريف - أ.م.د. خالد مقبولـ أ.د

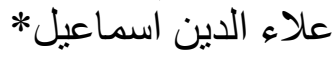

قسم علم الحيوانـ كلية البنات للأداب و العلوم و التربيةـ كلية الطب *- جامعة عين شمس.

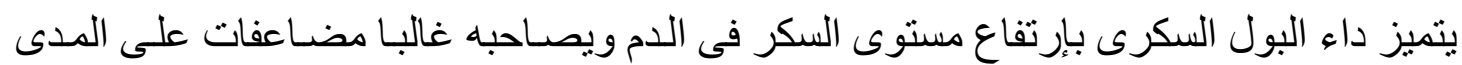

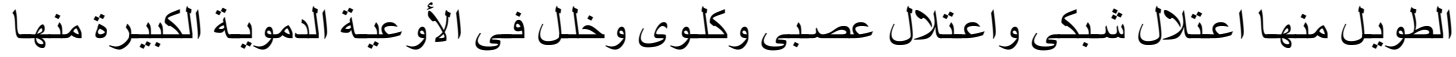

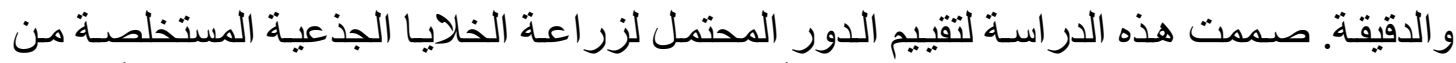

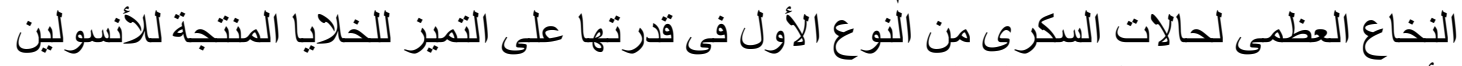

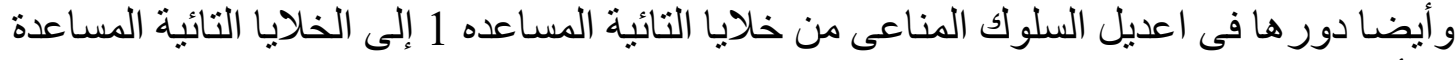

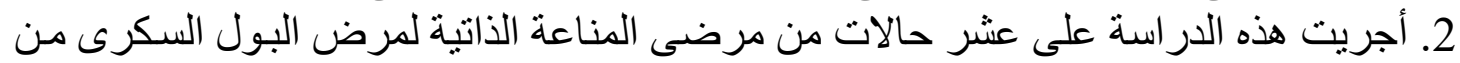

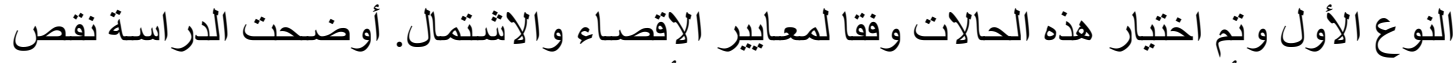

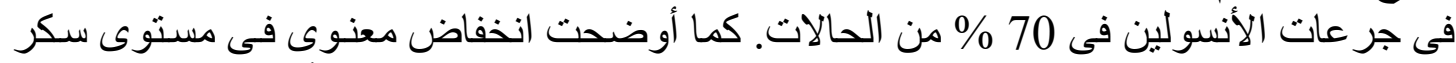

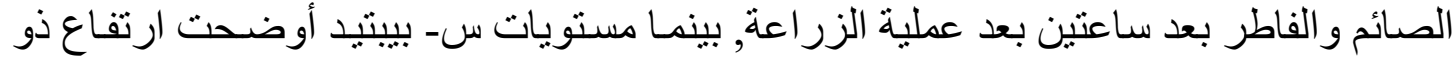

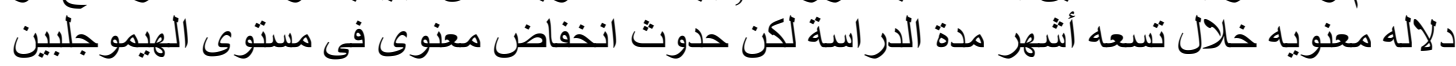

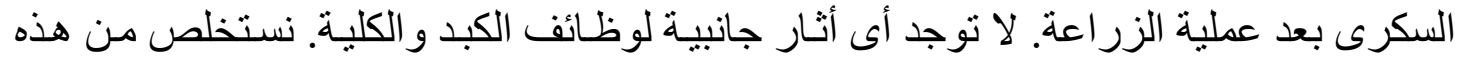

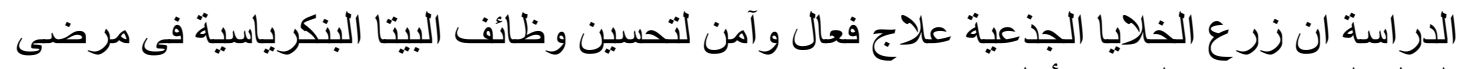

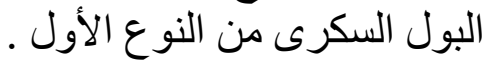

